\title{
Middle East Instability, After the Arab Spring \& It’s Impact on the United States’ and Egypt’s Bilateral Relations
}

\author{
A. Y. Zohny \\ Coppin State University, Baltimore, USA
}

\begin{abstract}
This work investigates the rise of political Islam in the Middle East and its impact on the United States' and Egypt's national interests and bilateral relations. In this article, the author describes the United States' foreign policy dilemma in dealing with the Arab revolutionary waves of 2010 and 2011, which was hijacked by political Islam championed by the Muslim Brotherhood's mother organization in Egypt. Also, how the United States and Egypt managed to navigate their strategic partnership for stability and peace in the region through developing tolerance of interference in one another's foreign policy making and reconciling their national interests within the complicated political, economic and social realities of the Middle Eastern region.
\end{abstract}

Keywords: bilateral relations, national interests, political Islam, revolutionary waves, tolerance of interference

\section{Introduction: National Interest \& Power}

Hans. Morgenthau (1904-1980) demarcated the relationship between national interest and power. He argued that power is the basic element of a nation state's ability to project and defend its national interests outside its borders and in international politics. Some elements of power such as a country's geography, natural resources, population, and economy-are tangible or calculable. Some of the most important factors, however-such as a country's military capability, the quality of its political system, and its determination (decisional latitude or ability to make decisions) — cannot be calculated until it is involved in a war or a national disaster, or a revolution.

Countries such as the United States and Egypt see their national interests through different lenses. Egypt is one of the oldest and most storied civilizations and countries in the world. For most of its long history, Egypt has experienced the mixed blessing of being at, or close to, the centers of world politics due to its geographic location. In the nineteenth, twentieth, and twenty-first centuries, the Suez Canal-the lifeline of international trade, the Cold War, the Arab oil embargo, and signing a peace treaty with Israel, and the Palestine issue were among factors causing the country to retain its status as a political lightning rod in the Middle East. The United States on the other hand and despite a decade of costly and indecisive warfare and mounting fiscal pressure, the long-standing consensus among American policymakers about U.S. national interests has remained remarkably intact. As the Presidential campaign of 2016 made clear, Republicans and Democrats may quibble over foreign policy at the margins, but they agree on the big picture of the U.S. national interests: that the United States

A. Y. Zohny, Ph.D., Chairman, Department of Applied Social \& Political Sciences, College of Behavioral \& Social Sciences, Coppin State University.

Correspondence concerning this article should be addressed to A. Y. Zohny, Coppin State University 2500 West North avenue, Baltimore, Maryland 21216. 
Should dominate the world militarily, economically, and politically, as it has since the final years of the Cold War, a strategy of liberal hegemony.

Currently, the power of political Islam seems to be the most challenging issue to Egypt's and the United States' national interests. As the Arab world's primary state, Egypt had little choice but to accept the burden of regional leadership. Today, Egypt must continue to confront the major regional challenge of political Islam championed by the Muslim Brotherhood (MB) mother organization in Egypt, with a network of alliances with various Islamic violent groups all over the Arab and Islamic countries, such as Al-Qaeda and ISIS—or ISIL. Egypt's ability or inability to pursue its national interests of neutralizing political Islam actually extends to the global level and can affect the national interests of the United States.

The rise of political Islam to the world stage has its threatening impact on the United States' national interests particularly after 9/11/2001. Most of the world sided with the United States after 9/11 and supported the U.S. overthrow of the Taliban regime in Afghanistan. NATO forces also, helped to try to stabilize the country because many European countries had national interests in fighting al-Qaeda, which had headquarters in Afghanistan. Currently, the U.S. is getting support from countries-members and nonmembers of NATO who joined a coalition (including Egypt) to fight ISIS after its rise as a political player in the Middle East as a result of the political vacuum accrued in Iraq after the U.S. withdrawal, and the Syrian, Libyan, and Yamen civil wars.

This paper will examine the regional dimensions of conflicts in light of the growing power of political Islam in the Middle East, and its impact on the United States and Egypt's national interests in the Middle Eastern Region and bilateral relations.

\section{The United States Dilemma}

The United States is still facing a unique dilemma in the Arab revolutions which are called the Arab Spring of early 2011. In that popular movements for democratic reform in countries like Egypt, Tunisia, Yemen, and Bahrain have put America in the position of watching the principles of democracy - the quality component of the American political system and national interests—used to challenge authoritarian governments that it had backed for decades (such as Presidents Hosni Mubarak in Egypt, Zeen al-Abedeen in Tunisia, Saleh in Yamen, and King Hamad Bin Isa Al Khalifa in Bahrain). In March 2011, the U.S. and its allies went to war to protect civilians in Libya, but many critics asked why it would not do the same in Bahrain and Syria. In the Arab states where popular uprisings have succeeded in changing leadership, such as Tunisia, Egypt, and Libya, the forces of authoritarianism, militarism, and tribalism persist and may negate the democratic demands of some of the demonstrators. It is too early to speak of a revolution and the Arab Spring has turned to bitter winters in countries like Egypt and Bahrain and turned to a civil war in countries like Syria, Libya, and Yemen where political Islam hijacked the revolutionary waves, and the Sunni-Shiite ideological rivalry in quest for influence in the region revived in the context of the dynamics of the Arab Israeli protracted regional conflict.

\section{The Rising Power of Political Islam}

While all Muslims share the core belief that there is only one God, and Muhammad was his messenger, the Sunni and Shite sects differ especially on the question of succession following the death of Muhammad. Although the majority Sunnis chose Abu Baker, Muhammad's best friend and early convert to Islam, as his successor, the Shia advocated Ali, Muhammad's cousin and son-in-law. Doctrinal and ritual differences 
continue to divide the two sects, depending on the locale, education, custom, politics, and personal attitudes of Muslims all over the world. The aforementioned diversity of perspectives found among twenty-first-century, Muslims was anticipated in the ideas of three early Islamic revivalists who lived in Egypt: Jamal al-Din al-Afghani, Muhammad Abduh, and Muhammad Rashid Rida. These well known late nineteenth and early twentieth century scholars and activists grappled with questions of modernity, social and political development and relations with the West, and came to different conclusions. Al-Afghani and Abduh, were inclined to meld Western ideas and institutions with Muslim values and society, whereas Rida emphasized Muslim genuineness and counseled a more conservative, more "fundamentalist" interpretation of what it means to be a Muslim, or Islamic Government. The conservative thought of Rida seems to be strongly influenced Hassan al-Banna, who founded the MB, usually referred to as the Ikhwan, in 1928 in the Ismailia Egyptian city, one of the three cities bordering the Suez Canal.

Nathan J. Brown argued that Egypt's MB social movement has set the pattern for other Islamist movements and many of the various movements it spawned in other countries of the Middle East that continue to refer to the original Egyptian organization as the "mother movement". The MB's unique organizational features of being flexible, with a focused vision, disciplined and engaging, its general emphasis on reform and the effective operation of its informal secret organization (MBSIO), have set the example and tone that other Islamic movements have tried to follow. The MBSIO's informally institutionalized behavior evolved, according to Saad Eddin Ibrahim, from the necessity of survival in the complicated realities of Egyptian politics in the last 84 years - under the monarchy for 24 years and under military dictatorships for 59 years. For all the MB's problems attaining legal status in the last 84 years, the MBSIO still strive to have bylaws, clear criteria for various graduations of membership, regular internal arrangements, established procedures for selecting officers, determining policies and positions, collegial and consultative decision making organs, and specialized bodies with clear functions tasks.

Since its establishment by Hassan al-Banna in 1928, the MB movement was used and abused by its members - and also by Islamists who constitute a broad category that includes diverse individuals converging on the goal of creating a sociopolitical, legal and economic order based on interpretations of Islam, not only as a religion, but also as a social and political system.

The MB's entry into political activity in Egypt began early but appeared cautious and almost diffident at first. In the 1930s, the organization eschewed tight political alliances but still found itself in rivalries among Egyptian political forces (sometimes earning itself a reputation for being close to the palace or to a political party). In addition to forming political alignments, MB's leader Hassan al Banna focused on a few specifically Islamist causes that had salient political overtones such as: Christian missionary activities, British imperialism, and the brewing conflict between Arabs and Jews in Palestine.

From 1923 to 1952, the MB was perceived by the capitalists liberal ruling elite (during the monarchy time), as part of the Egyptian political landscape. It played an important role in the struggle against the British and the Zionists in Palestine. During the 1940s (particularly during and after WWII's complicated events), the MB got caught several times in the power struggle between King Farouk, the British ambassador (the De Facto ruler of Egypt), and other political parties. The MB was outlawed and its activities were suspended when their MBSIO’s militia assassinated the prime minister of Egypt, Mahmud Fahmy al Nokrashy (1946). After the 1952 revolution and two years of a honeymoon between the MB and the free officer's corp (who ousted King Farouk), leaders of the MB got caught in the power struggle between Nasser, supported by the majority of the 
free officers, and General Mohamed Naguib, the figure head of the July 1952 revolution that ousted the Egyptian monarchy. Naguib had favored the restoration of Egypt's parliamentary democracy; Nasser favored a continuing populist revolution under the supervision of the military. The MB was in the middle of these power struggles and they planned and implemented the unsuccessful assassination attempts on Nasser's life in 1954. But Nasser refuted the above arguments in a public televised speech in 1965, arguing that the MB wanted to control political power to build an Islamic state where the Holy Quran would replace the constitution, Islamic Jurisprudence would be the law of the land, women ought to wear haijab and stay at home to raise children, all entertainment outlets such as movies and theaters should be abandoned. And the abundance of all western institutions such as political organizations. Furthermore, Nasser revealed to the public that while the free officers were negotiating with the British to end their occupation of Egypt, leaders of the MB were doing secret negotiations with the British government to allow them (the British) to continue having permanent military basis in the Suez Canal Zone. The bargain consideration was to enable the MB to be in power. Consequently, the MB was outlawed by the RCC the Governing Council of the Egyptian revolution and considered to be a threat to Egypt's national security. MB leaders and a large number of members were tried, executed or jailed for a long time without a fair trial in some cases.

In describing the relationship between the Egyptian military and the MB, Goldschmidt noted,

that the 1952 revolution had been a classic army coup, not a popular uprising. If the free officers wanted to gain and hold the people's support, they had to appeal to groups and/or social movements that have wide popular support at the grass roots level, even if these groups or social movements have different views of the free officers' corps.

The MB satisfied these attributes and the free officers cooperated with them to strengthen the Revolutionary Command Council's RCC's power over the entire Egyptian state. Nasser tolerated MB, but once the RCC was clearly in control of the government, it could no longer share power with its rivals, among them the MB, old regime politicians, communists, trade unions, Al-Wafd party and other political parties and social movements operating in Egyptian politics.

Saad-Elddin Ibrahim noted that, even though the MB had been outlawed, its secret informal underground organization (MBSIO) continued to operate through person to person contacts in every Egyptian village and city, using forums that could support their activities and incubate it far from Nasser's security apparatus.

The growing power of political Islam in the last 40 years with its defining features of Egyptian society goes back to the early 1970's when President Sadat of Egypt (1971-1981) used the MB and other Islamic movements to advance one of his political goals of gradually moving away from Nasser's socialist ideology. Sadat unleashed Egypt's Islamic forces including the MB when he released thousands of the MB's leaders and members from jail, and allowed the MB's old newspaper the Call (Al-Dawaa) to be reissued. He encouraged them further by trying to assume the mantle of Islam, calling himself "the guardian of the faith". Also, he emphasized that his first name was "Mohamed," not "Anwar." He promoted religious schools by authorizing a major increase in the budget of Al-Azhar University and the expansion of its parallel education system. Sadat also, opened the door for leading religious commentators to dominate the state-controlled media. Furthermore, he introduced apostasy laws in Egypt after years of a highly liberal intellectual atmosphere, and declared sharia law (Islamic jurisprudence) as the principle source for the Egyptian constitution and declared himself the leader of "an Islamic pious country." In less than a decade, the Egyptian state became quasi-Islamic, replacing the civic secular nature of the 1950s and 1960s under Nasser. To consolidate his power, Sadat felt that Islamic 
groups including the MB would counterbalance the combined opposition to his regime mounted by Nasserite and leftist elements.

Despite the fact that the MB was allowed to operate tacitly during the Sadat regime, other Islamic movements such as the Sufi, the retreats movement, the Salafist, Repentance and Holy Fight (RHF), and the Islamic Liberation Organization (ISO) — none of them were able to acquire a legal status or license through the Ministry of Social Affairs. The (MBSIO) was able to operate more freely in the informal realm, than any other Islamist organization in Egypt during Sadat's Regime due to the successful social services it provided to the poor population in the urban and rural areas.

During this period, the MB vision of political Islam emphasized two operational principles—one strategic and one tactical. The strategic principle is an assertion of its longstanding call for the establishment of an Islamic social order on the basis of the Shari'a. The tactical principle is the assertion that the MB is seeking its strategic objective in Egypt nonviolently through consciousness raising of the Muslim masses and advice to "Muslim” rulers. The MB's leadership has detached itself from other Islamist groups which engaged in violent confrontation against the Sadat regime. But the MB, however, through the MBSIO, was able to cautiously form an opposition to the four major policies initiated and implemented by Sadat, which from their point of view proved to be harmful to Egypt: the open door economic policy, the western style democratization, alliance with the west and conciliation with Israel. Due to the resistance of all the Islamic movements operating in Egypt under the wings of the $\mathrm{MB}$, the aforementioned policies were implemented by the government with repression measures concurrently.

\section{The Role of the MB in the Egyptian Revolutionary Waves}

\section{The Egyptian Revolutionary Wave of January 25, 2011}

During the 30 years of Mubarak's autocratic regime, the MBSIO continued to operate in the informal realm, and participate in the Egyptian policy process, despite the fact that the Egyptian security apparatus regained and even exceeded the powerful role it played under Nasser (1952-1970). With the overwhelming grip of the state through its coercive apparatus on political life, and the increasing economic needs that have gone unmet, the Egyptian people have resorted to the traditional informal modes of participation to access resources, curry favors, and have a voice in everyday political, economic and social matters. As recently as December 2010, the MB's leadership members were routinely rounded up by security forces (including the elected president Mohamed Mursi). Mubarak’s regime had manipulated the November 2010 election even worse than usual, leaving the MB with zero seats in parliament (compared to their previous share of eighty-eight seats, or 20 percent of seats in the 2005 parliamentary election). Nazih Ayubi notes, since the Egyptian state has managed to encircle the society to this extent, the MBSIO enabled the people (particularly in the poor rural and urban areas) to get engaged through forums near to where they live. This includes the mosques, Zawayas (very small Mosque), religious orders and brotherly solidarity that have been re-embraced by the popular forces, at a time when nationalist and leftist elites are still struggling to turn their civil associations and societies into viable structures for rejuvenating the civil society. Ibraheim Essa reported in his popular TV program, Cairo today, that Egypt has 120,000 Mosques and Zawias used by the MB for their political activities, and social services programs. And only 5,000 cultures and athletic centers operated by the Ministry of culture and Ministry of Youth \& Sports of whom one half of them understaffed or not working due to budgetary constraints, no wonder the political power and influence of the MB was growing every day in the last 40 years of the Sadat and Mubarak regimes. 
Members of the MB did not join other political forces such as Al Wafd, Kafia or 6 of April, or the Nasserists in the streets until January 28, 2011, and after they were certain of the success of the January 25, 2011 revolution. Shadi Hamid noted that,

for the members of Egypt's MB - the oldest and most influential and disciplined Islamist force - the Arab Spring and the January 25, 2011 revolution against Mubarak may not have been of their making, but it surely was the answer to their prayers.

The leaderless revolution posed a rare opportunity for the MB's leaders to have a free ride to realize their 80 year old dream of ruling Egypt and make it a springboard for an Islamic nation far beyond Egypt geographic boundaries governed by Sharia Law. To do so it was necessary for the MB to destroy the three components of Egypt's authoritarian regime which ruled Egypt for 60 years: the military, the security services and the political apparatus according to Hazem Kandil. As it will be explained.

\section{The MB Hijacking the Revolution}

Mubarak’s resigned on February 11, 2011, responding to popular demands and after the military took a clear position of siding with the Egyptian People. In violation to the Egyptian constitution of 1971, he handed power to the Supreme Council of the Armed Forces (SCAF) — made up entirely of military officers instead of the Speaker of the People's Assembly (the lower Chamber of the Parliament). From January 28/2011 on, the MB started to implement their goal of destroying institutions of the Egyptian state with the help of the Palestinian Hamas, the offshore agency of the MB in the Gaza Strip. It is reported by the Egyptian government and other reliable sources in the security establishment that at least 5,000 heavily armed Palestinian members of Hamas mobile on fully equipped four wheel vehicles illegally crossed the Egyptian Palestinian borders via the 1,200 underground border tunnels. They arrived to Cairo and large cities gradually. Their movements were coordinated and led by the MBSIO militias. Their first task was to free leaders of the MB including the ousted President Mursi by Force from Egyptian jails, attacking police stations and creating an environment of fear and chaos among the Egyptian people demonstrating peacefully in the streets. Some members of the MBs and Hamas sharp shooters ware Police and Army uniforms while positioning in the roofs of building surrounding the Thahreer Square down town Cairo, while shooting on the crowds indiscriminately. By March 2011, the political apparatus of Hosni Mubarak symbolized in the National Democratic Party (NDP) was destroyed. Its leaders fled the country or were arrested. Its members were called al-fellol or remnant of the old regime. The NDP headquarter in Cairo was burned down likewise its offices all over the Egyptian provinces. The first task of destroying the political apparatus of the Egyptian state was completed without much effort from the MB because all other political forces were determined to destroy it. Then the MB turned to the other components of the invidious triangle of political power in Egypt, the security services and the Army as it will be explained in the following paragraphs.

While SCAF trying to exercise executive authority directly and via an interim cabinet headed by Prime Minister Essam Sharaf who has almost no power, leaders of the MB were putting their MBSIO aided by the Palestinian Hamas fighters, Al-gama al Islamia and some Salafests into violent streets operations with the objective of undermining the credibility of the already unpopular Egyptian police of maintaining order and protecting citizens. The violent acts resulted in the killing of at least 850 persons and wounding at least 5,000 others. With the denial of the Army and the Police committing these acts against the peaceful demonstrators, the suspicious pointed out to an active third party without known identity at that time. This unknown actor with 
superior arms and tactical fights took the already demoralized and exhausted police force by surprise everywhere, and marginalized their role for protecting public order.

On the political front, members of the MB betrayed all other political forces ignited the revolution and made side deals with SCAF to give the military assurance of the continued military privileges in the new political order. Hence, SCAF oversaw a March 2011 referendum that approved amendments to Egypt's constitution. Amendments divided the country and made Egypt's direction toward democracy without a clear road map. SCAF also, issued new laws on the formation of political parties which enabled the MB to form their first political party-The Justice \& Freedom Party (JFP) and the conduct of parliamentary elections. The amended constitution laid out a transitional framework in which the elected People's Assembly and Shura Council, in conjunction with the SCAF, were to select members for a 100-person Constituent Assembly to draft a new constitution subject to a referendum.

Legislative elections held in late 2011 and early 2012 granted significant majorities to Islamist political parties, including the Muslim Brotherhood's Freedom and Justice Party (FJP). The SCAF and various non-Islamist forces challenged the legislature's efforts to select members for the Constituent Assembly, and a court ruling found the legislative electoral law unconstitutional, putting the recent election results and the future of the Islamist-dominated parliament in doubt. As polls closed for the final round of Egypt's June 2012 presidential election, the SCAF issued further amendments to the transitional constitution, granting itself sweeping powers to appoint members of the Constituent Assembly, enforce martial law, and remain immune from oversight by the newly elected President Muslim Brotherhood candidate Mohammed Morsi, and any future elected parliament.

Marina Ottaway, noted at that time that Egypt faces three major and related political challenges to a successful democratic transition to a civil society: the role the military is playing and will continue to play; the presence of powerful Islamic forces, not only the (MB), but also, the Salafi groups and al-Gama'a al-Islamiyya; and, somewhat more un-expectedly, the growing reluctance of some self-proclaimed democrats to put the future of the country in the hands of a democratic process.

On July 1, 2012, Mohamed Mursi the MB candidate was sworn to office after giving assurance to all political forces that he will be the President of all Egyptians. And with the blessing of the United States and the EU. After 60 years of enduring a military regime, Egypt seemed to be finally witnessing a transition toward democracy.

\section{The MB and the Second Revolutionary Wave of June 30, 2013}

Mohammed Mursi's first year in office turned out to be disastrous. He governed with an autocratic style, refusing to offer concessions to opponents and making little effort to reach beyond his Ashiera (his Muslim Brotherhood group) to gain new allies. Morsi ruled as if he was answerable only to his Brotherhood, and to hell with the $48 \%$ of the electorate who did not vote for him. In November, 2012, he issued a Presidential decree that temporarily granted himself powers beyond the reach of any court; the decree allowed a Brotherhood-dominated assembly to draft a new constitution, which most experts described as badly flawed. Morsi threatened to shut down some television stations that broadcast opposition views, and some prominent critics were arrested and interrogated in the headquarter of the MB in Mokatam by members of the MB. During Mursi's one year in power the MBSIO started to create another security apparatus parallel to the Ministry of Interior and the Egyptian Intelligence Service. They purchased with government funds, up to date surveillance 
and spying devices on other secular and liberal political forces with the approval of the Attorney General appointed by Mursi (an appointment took place without the consent of the Supreme Council of the Judiciary as required by Egyptian Law). But the worst problems were economic. Mursi handpicked Prime Minister Hisham Kandell and his team was incapable of meeting obligations for a much needed loan from the International Monetary Fund. Also, Egyptians suffered frequent shortages in electricity supplies, food and other basic needs dependent on imports with hard currency.

Parallel to breaking down the state security apparatus infrastructure and dismantling the State Security Investigation Agency Mabaheth Amn Al-Dawla, the MBSIO started a campaign to undermine the Egyptian military in the Egyptian society. These activities started by generating rumors against leaders of the armed forces, or initiating frivolous legal actions against them accusing them of corruption. The term dawn al-Askar which is an Arabic term connoted an insult to the Egyptian military and was used frequently by MB leaders, other Islamic TV stations, and frequently repeated in planned demonstrations after every Friday prayer.

After their candidate Mohammed Mursi came to power by democratic means, the MB's culture remained profoundly undemocratic. It has a rigid hierarchy, with a number of figures occupying higher positions than Morsi's had been. Many Egyptians were disturbed when these unelected leaders issued public statements during national crises. MB members who held public office continued to function with secrecy and the insularity of a banned group, and they seemed incapable of trusting outsiders. Within the MB's organization, there is a tradition of strict obedience to superiors. This makes the MB highly disciplined but also unresponsive to change. Their leaders are out of touch, perhaps because subordinates told them what they wanted to hear.

In the first three month of his presidency, Mursi pardoned a significant number of criminals who were sentenced for high crimes (Felonies: 25 years or life in prison), and allowed around 12,000 Jihadist from all over the world to obtain entry visa and residence in Sinai. They were given sanctuary (Safe haven) in the already troubled Sinai Eastern region with border with Israel and Gaza Strip. These Jihadists committed acts of violence included exploding the Gas-Pipeline between Egypt and Israel and Jordan, killing Police officers, and burning state building in all towns of the two Governorates of Sinai bordering Israel and Gaza Strip.

Toward the end of Mursi's first year in office the Egyptian army was perceived by the Egyptian public as not capable of playing its original mission of maintaining Egyptian national security because of its involvement in politics. After Mursi and the MB failure to penetrate the Military's organization ranks which remained loyal to General Abdel fatah al-Sisi (the commander in chief of the Egyptian Army and Minister of Defense), it was decided by the Supreme Guidance Office of the MB that it is time to create another non Egyptian parallel army or armed Militia of one hundred thousand Jihadist which would be supplied by Iman Al Zawhry the Leader of Al-Quada in Afghanistan. These reports were leaked on Face book, twits of members of the MBs and reported by various Egyptian TV stations, public and private in the first week of June 2013. And prior to the Army move to remove Mursi from office. A move or a coup which was legitimized by the popular movement of Tamarrod means Rebellion. After only one year of democratic leadership, Tamarrod enabled the crowds to take over again, and control the direction of the Egyptian policy process. In other words, Tamarrod moved Egypt's democratic process from representative democracy to a direct democracy. The 33 million afoot on June 30, 2013 persuaded Egypt’s powerful Military apparatus to remove President Mohammed Morsi after his first and only year in office. Tamarrod political movement started in late April 2013 when five activists, who ranged in age from 22 to 30, had come up with the idea of a petition campaign that rejected the Morsi Presidency. 
The majority of Egyptian people comprised moderate, liberal, socialists forces that opposed political Islam as practiced by the MB endorsed Tamarrod political movement. And embraced the military to finish off Morsi. By embracing the military to remove Mursi, the political opponents abandoned the democratic process for which many of them had risked their lives two and a half years ago. Tamarrod gave a final count for the petition campaign: 22,134,465, one week prior to the army move to oust Morsi from Office, which legitimized this coup to the international community and made it in response to the people's demands.

Organizers of the Tamarrod political movement seemed uncertain about what to do with all these petitions. They talked vaguely about having them certified by the Supreme Constitutional Court, or maybe the United Nations. But again the Egyptians did it! They came up with a new innovative idea which needed to be studied by political scientists. Political science is part of the political world. It constitutes the political world, and is constituted by the political world. On this latter point, David Garson concluded almost four decades ago that "political science grows largely reactively, in response to outside stimuli... rather than through the self-conscious testing of analytical models”. Egypt's political changes in the first and second revolutionary waves of 2011 and 2013 certainly rank as internal stimuli that should help grow political science. Popular as it was, the Egyptian Army coup sets a precedent for transferring power not by the ballot box but by the citizen in the street controlling and directing the policy process of their country from the streets. And it broadcasts a clear signal to Islamists everywhere in the countries of the Arab Spring in the Middle East that elections are exactly what the extreme among them have always warned: pointless.

The events surrounded the army coup, however, and may indicate that the powerful military and security apparatus, the custodians of violence, are not like other pressure groups and are willing to bargain with the MBs or other civilians to promote their interests. Their corporate interests are entwined in the mind of their members with the nations' national security (maybe even its existence). The MB's hijacked the January 25, 2011 first wave of the revolution drawing on their 80 years of organizational experience and discipline, but their candidate was removed from the Egyptian Presidency by the organization of a political movement which is a sixty-day-old-Tamarrod. A sixty-day-old organization gave the military and the security apparatus the legitimacy and opportunity to save Egypt from unknown course and uncertain future under the MB. An 80 years old social movement which does not recognize or respect Egypt as a state and one of the most celebrated civilizations and perceive it as a part of an unidentified Islamic nation.

\section{The MB's Failure to Govern}

The MB's failure to govern in Egypt is definitely a blow to political Islam in the Middle East. Egypt is a trend setter for the Middle East by virtue of its population (90 million), human resources technical knowhow, cultural influence (soft power: i.e. movies, arts and entertainment industry) and its armed forces which are ranked No. 14 worldwide. The failure of the MB to govern in Egypt as expressed by the latest Egyptian Court ruling to outlaw the $\mathrm{MB}$ and its vast social services network could be a devastating blow to political Islam in Egypt and the Middle East. The international organization of the MB is likely to be dismantled by all governments of the region.

This particularly, after the acts of violence committed in all Egyptian cities which resulted in the killing of hundreds of innocent Egyptians, and damages of public and private properties and many churches in Egypt's south. Also, it became clear and by convincing evidence that the MB has strong ties with terrorist organizations and possibly, it is the incubator of the terrorist Islamic organizations currently operating all over the Arab and 
Islamic world. The secular and liberal forces within the Arab Spring countries of Tunisia, Libya, Yemen, Bahrain and Syria are likely to follow Egypt in reject of the MB's vision of political Islam. An experiment was encouraged unfortunately and advocated by the U.S.A. Current development in Tunisia and Libya's political transition may indicate this trend of fear from the growing power of political Islam. The military and security apparatus cooperated and united to defeat the MB not only to regain their power position in Egyptian politics, but also, to protect Egypt's special identity and culture evolved over more than seven thousand years. Also, to protect Egypt's religious leadership as a leader of a moderate tolerant Islamic theology and the science of Islam developed by 1,400 years by Al Azhar institution's scholarship.

\section{Reconciling United States' and Egypt's National Interests}

Within the aforementioned complicated realties of the Middle Eastern region how can the United States and Egypt realize their individual pursuit of national interests without jeopardizing their bilateral relations? The answer to the aforementioned question can be answered in light of the following facts presented by the Egyptian Ambassador in Washington DC:

First: Because of its regional influence and geographic location, Egypt is America's key partner on shared goals of peace and stability throughout the Middle East, North Africa and beyond. The two countries maintain close military-to-military relations, predicated on the shared view that a strong and modern Egyptian military contributes to regional stability. The U.S.-Egypt relationship has also grown to include cooperation on counter-terrorism, the Israeli-Palestinian peace process, peacekeeping operations in Africa, deepening regional economic integration and other shared endeavors.

Second: The 1979 Egypt-Israel Peace Treaty has been a crucial foundation for all subsequent efforts toward broader peace in the Middle East. Continued Egypt-U.S. collaboration is integral to further progress on Israeli-Palestinian peace. Secretary of State John Kerry praised Egypt's "pivotal role” in fostering a long-term ceasefire between Israel and Hamas following weeks of bloodshed in Gaza in 2014. Egypt subsequently hosted a donors conference raising over $\$ 5$ billion for reconstruction efforts.

Egypt is an active participant in the United Nations peacekeeping operations. It participated in eight out of the 15 operations currently underway worldwide, with a total of 2,613 personnel. Egypt is ranked 10th among the international contributors to peacekeeping operations key to international stability.

Third: As coalition partners against the Islamic State in Iraq and Syria (ISIS), Egypt is working with the United States and the international community to provide intelligence, cut off sources of terrorist funding and recruitment, and utilize Egypt's esteemed religious institutions to discredit extremists and promote moderation and tolerance. Senior Egyptian officials participate in coalition meetings around the world to better coordinate strategy and operations. And President El Sisi is leading the Arab world in evoking a new dialogue to confront fringe extremism. He has called on the nation's leading clerics to reinforce the tolerant teachings of Islam and reject radicalism, undercutting one of the root causes of terror.

Fourth: The United States is Egypt’s largest single trading partner, with volume reaching \$6.8 billion in 2013. Each year, Egypt expands and deepens its trade and investment relationship with the United States.

Recent bilateral exchanges underscored the renewed vitality of Egypt's economy and the importance of ongoing economic cooperation. In October of 2014, U.S. Treasury Secretary Jack Lew travelled to Egypt and announced a \$200 million package to support Egypt's economy. During his visit, Secretary Lew stressed the importance of the commercial relationship between our countries, stating that the "well-being of the Egyptian economy is an important US interest." The following month, 150 executives from nearly 65 major US companies travelled to Egypt and made history as part of the Chamber of Commerce's largest international trade delegation. 
Private sector engagement with U.S. government support will continue to be a vital component of our economic partnership for years to come. U.S. exports to Egypt grew 25 percent in 2014. Egypt remains the third largest Arab market for U.S. goods and among the top 10 foreign direct investors in Egypt. The largest American company doing business in Egypt, Houston, Texas' Apache Corporation, has investments totaling over \$10 billion. Other prominent American companies—including Coca Cola, General Motors, Johnson \& Johnson and Marriott, among others—consider Egypt a major regional business hub. Illinois’ Great Lakes Dredge and Dock Company was one of a select group of companies awarded a contract to help dredge a second channel in the Suez Canal. U.S. Government development agencies help facilitate public-private collaboration that allows US companies to enter or expand operations in a growing foreign market.

Fifth: Egypt and the United States also are partners in liberalizing trade relations, including the inclusion of Egypt as a beneficiary country under the U.S. Generalized System of Preferences (GSP) and the establishment of Qualifying Industrial Zones (QIZs), which allows duty-free entry to manufactured goods combining Egyptian and Israeli components from designated industrial areas. Egypt and the United States finalized a Trade and Investment Framework Agreement (TIFA) in 1999. Approximately 37 percent of Egypt's trade with the U.S. is routed through Texas and Louisiana, and the Port of South Louisiana is the premier site for wheat and oilseed imports to Egypt.

Egypt's exports to the United States are among the most diversified in the Middle East, including petroleum, apparel, fertilizers, chemicals and textiles. Egypt's investments in the United States witnessed a significant boost in 2011 when Egyptian Orascom Construction Industries (OCI) invested \$1.8 billion to create the Iowa Fertilizer Company (IFC). The plant is under construction and currently employs 1,900 construction workers in rural Iowa, representing the single largest investment in the history of Iowa and creating in total roughly 2,500 employment opportunities.

America's Economic Support Funds are another pillar of our economic partnership, contributing to economic growth and supporting Egypt's efforts to provide vital social services to our most vulnerable citizens.

The United States’ point of view is well articulated by Jermy M. Sharp, the Middle East Specialist of the Congressional Research Services. He argued that:

In the last few years, Egypt has presented serious challenges to U.S. policymakers seeking to balance competing priorities. On the one hand, the Obama Administration would like to see Egypt move toward a more democratic form of government and market-based economy in order to address the grievances of its relatively young population. On the other hand, Egypt's military, which has cultivated little in terms of democratic practices and institutions since the end of Egypt's monarchy in 1952, remains the country's primary political actor, a reality that may benefit short term U.S. national security interests. If the United States fully embraces the military, it risks alienating those Egyptians who espouse liberal democracy or an Islam-based system of governance. If the United States emphasizes democracy, Egypt's security apparatus typically turns against it, accusing American diplomats of, among other things, supporting the Muslim Brotherhood, spreading neo-colonialism, and undermining Egypt's stability.

The United States has provided significant military and economic assistance to Egypt since the late 1970s. Successive U.S. Administrations have routinely justified aid to Egypt as an investment in regional stability, built primarily on long-running cooperation with the Egyptian military and on sustaining the 1979 Egyptian-Israeli peace treaty.

U.S. policymakers are now debating complex questions about the future of U.S.-Egypt relations, and these debates and events in Egypt are shaping consideration of appropriations and authorization legislation in the 114th Congress Between 1948 and 2015, the United States provided Egypt with \$76 billion in bilateral foreign aid (calculated in historical dollars—not adjusted for inflation), including \$1.3 billion a year in military aid from 1987 to the present. This report discusses the conditions governing the release of these funds. All U.S. foreign aid to Egypt (or any foreign recipient) is appropriated and authorized by Congress. All U.S. military aid to Egypt finances the procurement of weapons systems and services from U.S. defense contractors. P.L. 113-235, the FY2015 Consolidated Appropriations Act, contains conditions on U.S. assistance to Egypt that are 
similar to what Congress included in the FY2014 appropriations act (P.L. 113-76), with one significant exception: an executive branch national security waiver in Section 7041(a)(6)(C) of the FY2015 act effectively permits the removal of limits imposed by Congress that would otherwise prevent the provision of assistance to Egypt until its government met democracy-based conditions. The Secretary of State exercised this waiver on May 12, 2015. For FY2016, the President has requested that Congress appropriate $\$ 1.3$ billion in military assistance for Egypt. The President also is asking Congress to provide $\$ 150$ million in economic aid. For FY2016, both House and Senate draft foreign operations appropriations bills (H.R. 2772 and S. 1725, respectively) would provide the full amount requested by the President.

\section{Concluding Remarks-Tolerance of Interference}

The very close ties between the United States and Egypt based on the aforementioned facts contributed to the development of a reciprocal tolerance of interference of one another's domestic and foreign policy making. These allowed the two parties to have long latitude of areas of agreement and areas of disagreement in their bilateral relations without allowing the later (areas of disagreement) to affect the strategic partnership between the two countries. The Obama administration coped adequately with the first revolutionary wave of January, 25, 2011, but beyond the expectations of the Egyptian people in dealing with the second revolutionary wave of June 30, 2013. As the performance of the U.S. Ambassador to Egypt-Ann Peterson was seriously criticized by the majority of Egyptian people, likewise the public statements made by Senator McCain of quoting the corrective action made by the Egyptian army based on Egyptian legitimized demands a coup. But Obama's statement before the United Nations general assembly of September 17, 2013 and to date February 2016, proved to reflect a better understanding of the complicated realities of Egypt's politics, and appreciation of the protective measures taken by the military and police against the destructive activities political Islam spear-headed by the MB to protect the Egyptian national security, and national interest.

\section{References}

Brown, N. J. (2012). When victory is not an option, Islamist movements in Arab politics. Ithaca: Cornel University Press.

Brownlee, J. (2011). Peace before freedom: Diplomacy and repression in Sadat's Egypt. Political Science Quarterly, The Journal of Public And International Affairs, 126(4), 642.

Goldschmidt, Jr. A. (2008). A brief history of Egypt. New York: Checkmark Books.

Hamid, S. (2011). The Arab awakening, America and the transformation of the Middle East. Washington DC: Brookings Institution Press.

Hessler, P. (2013). The showdown, winners and losers in Egypt’s ongoing revolution. The New Yorker, (July 22, 2013$), 28$.

http://www.egyptembassy.net/egypt-us-relations/ 2, 13, 2016

Ibrahim Aissa, Cairo Today, TV, (9/22/2013).

Ibrahim, S. E. (1996). Egypt, Islam and democracy, twelve critical essays. Cairo: The American University in Cairo Press.

Ikenberry, G., \& Trubowitz, P. (2015). American foreign policy, theoretical essays (7th ed.). New York: Oxford University Press.

Kandil, H. (2012). Soldiers, spies, and statesmen, Egypt's road to revolt. London: Verso.

Kay, S. (2015). Global security in the twenty-first century, the quest for power and the search for peace (3rd ed.). New York: Rowman \& Littlefield.

Khalil, A., \& Newton-Small, J. (2013). Washington, “Street Rule”. Time, (July 22, 2013), 30-35.

Norton, A. R. (2002). Activism and reform in Islam. Current History, A Journal of Contemporary World Affairs, 101(658), 377.

Osman, T. (2010). Egypt on the brink, from Nasser to Mubarak. New Haven: Yale University Press.

Ottaway, M. (2012). Good news before more battles in Egypt. Carnegie Endowment for International Peace.

Roskin, M., Cord, R., Medeiros, J., \& Jones, W. (2014). Political science, an introduction (13th Edition). Boston: Person Education, Inc. 
Sharp, J. M. (2015). Egypt: Transformation under military rule. (Congressional Research Service-CRS Report for Congress, prepared for members and committees of Congress, Washington, DC, 2015), 1.

Sherif, A. E. (2011). Islamism after the Arab Spring. Current History, A Journal of Contemporary World Affairs, 110(740), 359. Springborg, R., \& Henry, C. M. (2012). Army guys. The American Interest, VI(5), 16.

Tschirgi, D., Kazziha, W., \& Mcmahon, S. F. (Eds.). (2013). Egypt’s Tahrir Revolution. Boulder: Lynne Rienner Publishers. 